\title{
Transplantation of insulin-producing cells from umbilical cord mesenchymal stem cells for the treatment of streptozotocin-induced diabetic rats
}

\author{
Pei-Jiun Tsai ${ }^{1,2}$, Hwai-Shi Wang ${ }^{3}$, Yi-Ming Shyr ${ }^{4}$, Zen-Chung Weng ${ }^{5}$, Ling-Chen Tai ${ }^{4}$, Jia-Fwu Shyu ${ }^{6 *}$ and \\ Tien-Hua Chen ${ }^{3,4^{*}}$
}

\begin{abstract}
Background: Although diabetes mellitus (DM) can be treated with islet transplantation, a scarcity of donors limits the utility of this technique. This study investigated whether human mesenchymal stem cells (MSCs) from umbilical cord could be induced efficiently to differentiate into insulin-producing cells. Secondly, we evaluated the effect of portal vein transplantation of these differentiated cells in the treatment of streptozotocin-induced diabetes in rats.
\end{abstract}

Methods: MSCs from human umbilical cord were induced in three stages to differentiate into insulin-producing cells and evaluated by immunocytochemistry, reverse transcriptase, and real-time PCR, and ELISA. Differentiated cells were transplanted into the liver of diabetic rats using a Port-A catheter via the portal vein. Blood glucose levels were monitored weekly.

Results: Human nuclei and C-peptide were detected in the rat liver by immunohistochemistry. Pancreatic $\beta$-cell development-related genes were expressed in the differentiated cells. C-peptide release was increased after glucose challenge in vitro. Furthermore, after transplantation of differentiated cells into the diabetic rats, blood sugar level decreased. Insulin-producing cells containing human C-peptide and human nuclei were located in the liver.

Conclusion: Thus, a Port-A catheter can be used to transplant differentiated insulin-producing cells from human MSCs into the portal vein to alleviate hyperglycemia among diabetic rats.

Keywords: Mesenchymal stem cell, Portal vein, Insulin-producing cells, Transplant

\section{Background}

Type $1 \mathrm{DM}$ is an autoimmune disease that is characterized by inhibited insulin production as a result of $\mathrm{T}$ cellmediated destruction of the pancreatic $\beta$ cells in the islets of Langerhans [1,2]. Transplantation therapies for type 1 DM include whole organ transplantation [3], transplantation of isolated islets $[4,5]$ and regeneration therapy [6]. Although the transplantation of both a whole organ and isolated islets has been successfully used in the clinical treatment of type $1 \mathrm{DM}$, a shortage of donors limits the widespread use of this treatment modality. Additionally,

\footnotetext{
* Correspondence: jiafwu.shyu@msa.hinet.net; chen_th@vghtpe.gov.tw ${ }^{3}$ Institute of Anatomy and Cell Biology, School of Medicine, National Yang Ming University, 201 Shih-Pai Road Section 2, Taipei 112, Republic of China ${ }^{4}$ Department of Surgery, Veteran General Hospital, Taipei, Republic of China Full list of author information is available at the end of the article
}

the quality of a donor's pancreas is an important criterion for islet isolation [7]. On the other hand, regeneration therapy, in which stem cells are stimulated to differentiate into insulin-producing cells that can be used to replace lost $\beta$ cells, is free of such supply limitations [8].

Mesenchymal stem cells (MSCs) were first isolated from bone marrow [9] and have the potential to differentiate in culture into muscle cells, adipocytes, osteocytes, chondrocytes [10-12], cardiomyocytes [13-16] and pancreatic $\beta$ cells [17]. Moreover, following systemic injection, MSCs have been shown to be incorporated into a variety of tissues, including bone $[18,19]$, muscle [20], lung [21] and epithelium [22]. Although insulin-producing cells can be developed from bone marrow MSCs [23], adipose tissue-derived stem cells [24], and human umbilical cord blood-derived 
mononuclear cells [25], the number of MSCs that can be cost-effectively isolated and differentiated remains a major limitation. We found that fibroblast-like cells from Wharton's jelly of the human umbilical cord were similar to MSCs in the bone marrow and could be induced to differentiate into adipogenic cells, osteogenic cells, cardiomyogenic cells, and insulin-producing cells $[26,27]$. Because MSCs from the umbilical cord can be easily isolated and expanded in culture, they may provide a novel source of cells for cellular type 1 DM therapies.

In this study, we first characterized the insulinproducing cells derived from MSCs of Wharton's jelly with modified three stages $\beta$ cell differentiation method [17]. Subsequently, we treated diabetic rats by transplanting the differentiated insulin-producing cells into their livers through the portal vein. Instead of using renal subcapsular space [28] or tail vein [29] transplantation, we used a specially designed Port-A catheter portal delivery system that has been used in human islets transplantation $[4,5]$. In this study, streptozotocin (STZ) was used to induce type $1 \mathrm{DM}$ because there is extensive evidence that hyperglycemia induced by STZ can be lowered by stem cell therapy [30-33]. STZ is a naturally occurring chemical that is toxic to pancreatic $\beta$-cells in mammals and can produce an animal model of type $1 \mathrm{DM}$. The aim of this study was to test the curative effect of transplanting insulin-producing cells differentiated from human Wharton's jelly MSCs into rat livers.

\section{Methods}

\section{Cell culture}

Institutional Review Board approval was obtained for all procedures. With the written informed consent of the parents, fresh human umbilical cords were obtained after birth and stored in Hank's balanced salt solution (Biological Industries, Israel) prior to tissue processing to obtain MSCs. The isolation of MSCs followed the methods set forth by Wang et al. [26]. Briefly, after removal of blood vessels, the mesenchymal tissue was scraped off the Wharton's jelly and centrifuged at $250 \mathrm{~g}$ for $5 \mathrm{~min}$. After centrifugation, the pellets were re-suspended in $15 \mathrm{ml}$ of serum-free Dulbecco's modified Eagle's medium (DMEM; Gibco, Grand Island, NY) containing $0.2 \mathrm{~g} / \mathrm{ml}$ of collagenase and incubated for $16 \mathrm{~h}$ at $37^{\circ} \mathrm{C}$. Next, the cells were washed, resuspended in DMEM containing 2.5\% trypsin, and incubated for $30 \mathrm{~min}$ at $37^{\circ} \mathrm{C}$ with agitation. Finally, cells were again washed, and cultured in DMEM supplemented with $10 \%$ fetal bovine serum (FBS; Sigma St. Louis, $\mathrm{MO}$, USA) and glucose $(4.5 \mathrm{~g} / \mathrm{l})$ in $5 \% \mathrm{CO}_{2}$ in a $37^{\circ} \mathrm{C}$ incubator.

\section{In vitro differentiation cultures}

Differentiation was carried out in three stages, as shown in Figure 1. At the fourth to sixth passage, after reaching a confluence of $70 \%$ the MSCs were induced to differentiate into islet-like cell aggregates. Differentiation was divided into three stages. Undifferentiated human mesenchymal stem cells (HUMSCs) were detached by HyQTase, diluted with SFM-A and centrifuged. Cells were counted for initial seeding density and $110^{6}$ cells $/ \mathrm{cm}^{2}$ were resuspended in SFM-A and seeded on ultralow attachment tissue culture plates (Corning, Fisher Scientific International, Hampton, NH, http://www.fisherscientific.com). SFM-A contained DMEM/F12 (1:1) (Gibco, Grand Island, NY) with $17.5 \mathrm{mM}$ glucose, $1 \%$ BSA Cohn fraction V, fatty acid free (Sigma-Aldrich), 1\% penicillin/streptomycin/amphoteric B (PSA; Biological Industries, Israel), $1 \mathrm{X}$ insulin-transferrinselenium-X (ITS-X; $5 \mathrm{mg} / \mathrm{l}$ insulin, $5 \mathrm{mg} / \mathrm{l}$ transferrin, $5 \mathrm{mg} / \mathrm{l}$ selenium), $4 \mathrm{nM}$ activin A, $1 \mathrm{mM}$ sodium butyrate, and $50 \mu \mathrm{M} 2$-mercaptoethanol. The cells were cultured in this medium for 2 days. On the third day, the culture medium was changed to SFM-B, which contains DMEM/ F12 (1:1) with $17.5 \mathrm{mM}$ glucose, 1\% BSA, 1\%PSA, ITS-X, and $0.3 \mathrm{mM}$ taurine. On the fifth day, the cell culture was replaced by SFM-C, which contained DMEM/F12 (1:1) with $17.5 \mathrm{mM}$ glucose, $1.5 \%$ BSA, ITS-X, 1\%PSA, $3 \mathrm{mM}$ taurine, $100 \mathrm{nM}$ glucagon-like peptide (GLP)-1 (amide fragment 7-36; Sigma Aldrich), $1 \mathrm{mM}$ nicotinamide, and $1 \mathrm{X}$ nonessential amino acids (NEAAs). For the next 5 days, the culture medium was exchanged with fresh SFM-C every 2 days [24]. The differentiation condition was modified from that previously established [27], and lasted for a total of 10 days.

\section{Immunocytochemical staining for C-peptide}

Control and differentiated cells on coverslips were fixed with $4 \%$ paraformaldehyde for 15 minutes, and washed with phosphate-buffered saline (PBS). A DakoCytomation EnVision+Dual system-HRP kit (DakoCytomation Inc, CA) and mouse anti-human C-peptide antibody (Chemicon, Billerica, MA) were used to stain the cells. Briefly, Dual Endogenous Enzyme Block solution was added to cover the coverslips for 10 minutes. Next, the cells were washed with PBS and incubated for $1 \mathrm{~h}$ at $37^{\circ} \mathrm{C}$ with mouse antihuman C-peptide monoclonal antibody (1:100). After washing with PBS, the coverslips were incubated for $30 \mathrm{~min}$ with labeled Polymer-HRP. After another round of washing with PBS, Substrate-Chromogen was added for $5 \mathrm{~min}$. Finally, the coverslips were washed with distilled water. Cell nuclei were visualized by incubating the coverslips for $5 \mathrm{~min}$ at room temperature with hematoxylin (Sigma Aldrich, St. Louis).

\section{Reverse transcriptase-polymerase chain reaction (PCR) analysis}

Total RNA was extracted from control and differentiated cells using RNeasy Purification Reagent (Qiagen, Valencia, CA). Subsequently, a $4 \mu \mathrm{g}$ sample was reverse transcribed 
Mesenchymal stem cell differentiation steps

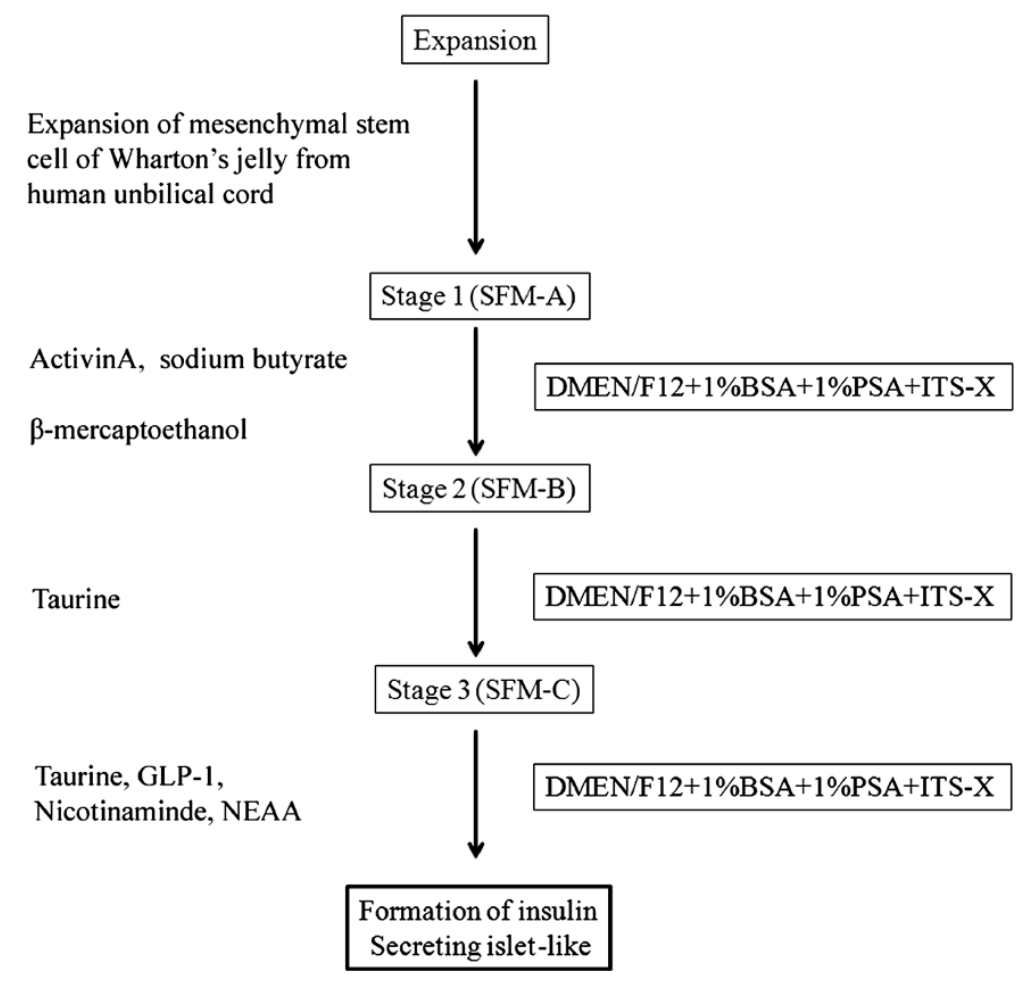

Figure 1 Diffenentiation scheme for generating insulin-producing cells from human umbilical cord mesenchymal stem cells.

with Mmlv reverse transcriptase (Amersham, Uppsala, Sweden) for $30 \mathrm{~min}$ at $42^{\circ} \mathrm{C}$ in the presence of an oligo$\mathrm{dT}$ primer. The PCR reaction mixture consisted of $38.5 \mu \mathrm{l}$ of sterile distilled water, $5 \mu \mathrm{l}$ of 10X PCR buffer, $1 \mu \mathrm{l}$ of $\mathrm{dNTP}, 1.5 \mu \mathrm{l}$ of each primer, $2 \mu \mathrm{l}$ of cDNA $(4 \mu \mathrm{g})$, and $0.5 \mu \mathrm{l}$ of polymerase $(5 \mathrm{U} / \mu \mathrm{l})$ (Amersham). cDNA was amplified for 30 cycles $\left(94^{\circ} \mathrm{C}\right.$ for $45 \mathrm{~s}$, annealing for $45 \mathrm{~s}$, and $72^{\circ} \mathrm{C}$ for $40 \mathrm{~s}$ ) using the following primer sequences: $P d x 1$ forward GGAGCCGGAGGAGAACAAG, reverse CTCGGTCAAGTTCAACATGACAG; Pax4 forward GGG TCTGGTTTTCCAACAGAAG, reverse CAGCGCTGCT GGACTT; insulin, forward GCTGGTAGAGGGAGCAGATG, reverse AGCCTTTGTGAACCAACACC; GAPDH, forward CACCATCTTCCAGGAGCGAG, reverse TCACG CCACAGTTTCCCGGA (Mission Biotech, Taiwan). PCR was performed for 30 cycles of denaturation at $95^{\circ} \mathrm{C}$ for $30 \mathrm{~s}$, annealing at $55-63^{\circ} \mathrm{C}$ for $30 \mathrm{~s}$, and elongation at $72^{\circ} \mathrm{C}$ for $1 \mathrm{~min}$, with a final $10 \mathrm{~min}$ extension at $72^{\circ} \mathrm{C}$. To exclude the possibility of contaminating genomic DNA, PCRs were also run without reverse transcriptase. The amplified cDNA was separated by electrophoresis on a 1\% agarose gel, stained, and photographed under ultraviolet light.

\section{Real-time PCR analysis}

cDNA was prepared from $4 \mu \mathrm{g}$ of total RNA as described above and $200 \mathrm{ng}$ of RNA equivalents was used for PCR with specific primers in the presence of SYBR Green I (Light Cycler $^{\text {TM }}$-FastStart DNA Master SYBR Green I; Roche, Basel, Switzerland). The sequences of the primers were as follows: $P d x 1$ forward GGAGCCGGAGGAGAACAAG, reverse CTCGGTCAAGTTCAACATGACAG; Pax4 forward GGGTCTGGTTTTCCAACAGAAG, reverse CAGCGCTGCTGGACTT; insulin forward ACC AGCATCTGCTCCCTCTA, reverse GGTTCAAGGGCT TTATTCCA; GAPDH forward CACCATCTTCCAGGAG CGAG, reverse TCACGCCACAGTTTCCCGGA (Mission Biotech). A LightCycler ${ }^{\circledR} 480$ (Roche, Indianapolis, IN) was used for real-time PCR.

\section{Measurement of spontaneous C-peptide secretion}

After 10 days of differentiation, the cells were washed with PBS and incubated for $3 \mathrm{~h}$ in DMEM-LG (5.5 mM glucose) (Gibco, NY). The medium was collected and stored at $-20^{\circ} \mathrm{C}$ until being assayed. C-peptide ELISA kit (Mercodia, Uppsala, Sweden) was used according to the manufacturer's instructions. Briefly, $25 \mu \mathrm{l}$ of the sample was added to $50 \mu \mathrm{l}$ of assay buffer in the wells of a 96-well plate coated with anti-human C-peptide antibody. The mixture was incubated for $1 \mathrm{~h}$ at $18-25^{\circ} \mathrm{C}$ on a shaker. After six washes with washing buffer, $100 \mu$ l of enzyme conjugate was added to the mixture and incubated on a shaker for $1 \mathrm{~h}$ at $18-25^{\circ} \mathrm{C}$. Next, $200 \mu \mathrm{l}$ of substrate TMB 
was added for $15 \mathrm{~min}$. Finally, stop solution $(50 \mu \mathrm{l})$ was added to the wells for $5 \mathrm{sec}$ and the absorbance was read at $450 \mathrm{~nm}$.

\section{Glucose challenge test}

After 10 days of differentiation, the cells were incubated for $1 \mathrm{~h}$ in DMEM-LG (5.5 $\mathrm{mM}$ glucose), and the medium was collected and stored at $-20^{\circ} \mathrm{C}$. Next, the cells were washed with PBS and incubated for $1 \mathrm{~h}$ in DMEM-HG (25 mM glucose; Gibco, NY) and the medium was collected and stored at $-20^{\circ} \mathrm{C}$. The C-peptide concentration was determined using the C-peptide ELISA kit.

\section{Laboratory animals}

A total of 18 male, 6- to 8-weeks-old Sprague Dawley rats, weighing between 350-450 g (Laboratory Animal Center, Yang-Ming University, Taiwan) were provided with food and water ad libitum and were housed on a 12-h light and 12-h dark cycle. The experiment followed institutional guidelines pertaining to animal welfare.

\section{Induction of DM with STZ}

One week after surgery, $30 \mathrm{mg} / \mathrm{kg}$ of STZ ((Sigma Aldrich) solution in acidified $0.9 \%$ saline $(\mathrm{pH} 4.5)$ was injected intraperitoneally into the rats on 3 consecutive days to induce type 1 DM.

\section{Transplantation}

Rats were divided into one control group (without STZ induction), and two transplantation groups, each of which consisted of six rats. One week after STZ induction, rats the experimental group were restrained and injected with $5 \times 10^{6}$ differentiated insulin-producing cells suspended in $0.1 \mathrm{ml}$ of normal saline, followed by a volume of normal saline equivalent to the volume of the Port- $\mathrm{A}$ catheter $(0.35 \mathrm{ml})$ to push the grafts into the portal vein. The control group underwent the same procedure, but was only injected with normal saline (STZ group).

\section{Physiological monitoring}

Body weight and blood sugar were recorded every week after transplantation. Sugar levels in the blood collected from the tail vein were measured using a blood glucose meter (Roche, Indianapolis, IN).

\section{Immunohistochemistry}

Eight weeks following transplantation the rats were sacrificed and perfused with $4 \%$ formaldehyde (Ferak, Berlin, Germany). Rat livers were cut into $0.5-1.0 \mathrm{~cm}^{3}$ pieces. The samples were dehydrated and embedded in OCT (Sakura Fintek, USA) in liquid nitrogen. The cryosections $(5 \mu \mathrm{m})$ were washed with PBS, then incubated overnight at $4^{\circ} \mathrm{C}$ with mouse anti-human nuclei monoclonal antibody (1:400; Chemicon, Billerica, MA), and rabbit anti-human C-peptide antibodies (1:100; Santa Cruz, Santa Cruz, CA). After washing with PBS, the slides were subsequently incubated for $1 \mathrm{~h}$ with Cy3-labeled goat anti-human IgG antibodies (1:200) and rhodamine conjugated goat anti-rabbit IgG antibodies (1:500) (both from Chemicon). The sections were mounted with mounting medium (Vector) and viewed on a fluorescence microscope.

\section{Statistical analysis}

Each series of experiments was performed in triplicate. The results obtained from a typical experiment were expressed as the means \pm standard deviation (SD). Statistical analysis was carried out using the SPSS 14.0 software program (Statistics Package for Social Sciences, SPSS Inc. Chicago, Illinois, USA). All continuous data were presented as mean \pm SD. Student's $t$-test was used to compare the means of two groups. Categorical variables were compared by $\mathrm{X}^{2}$ test or Fisher's exact test. A P value of less than, or equal to 0.05 was considered to be statistically significant.

\section{Results}

\section{Gene expression in the differentiated cells}

To determine whether the MSCs had differentiated into insulin-producing cells, the expression of genes involved in pancreatic $\beta$-cell development and insulin production was examined by reverse transcriptase-PCR and real-time PCR. As shown in Figure 2, the pancreatic $\beta$-cell developmentrelated genes Pax1, Pax4, and insulin was expressed in differentiated medium. However, the expression of Pax1, Pax4, and insulin was significantly greater in differentiated IPCs versus undifferentiated MSCs (Figure 2).

Detection of C-peptide in the differentiated cells derived from mesenchymal stem cells from the umbilical cord

Anti-human C-peptide antibodies revealed that C-peptide was expressed in undifferentiated MSCs and differentiated IPCs. However, the expression of C-peptide was greater in differentiated IPCsthan in undifferentiated MSCs (Figure 3A). As illustrated in Figure 2B, the expression of $C$-peptide level increased several-fold from MSCs cultured in SFM-A, SFM-B and finally SFM-C (Figure 3B).

\section{Immunofluorescent staining for C-peptide}

The results of immunofluorescent analysis of the protein expression in insulin-producing cells cultured in Control, undifferentiated and differentiated MSCs were shown in Figure 4. The Cellular aggregation occurred as a gradual process in undifferentiated MSCs and complete aggregates were formed in differentiated IPCs. 

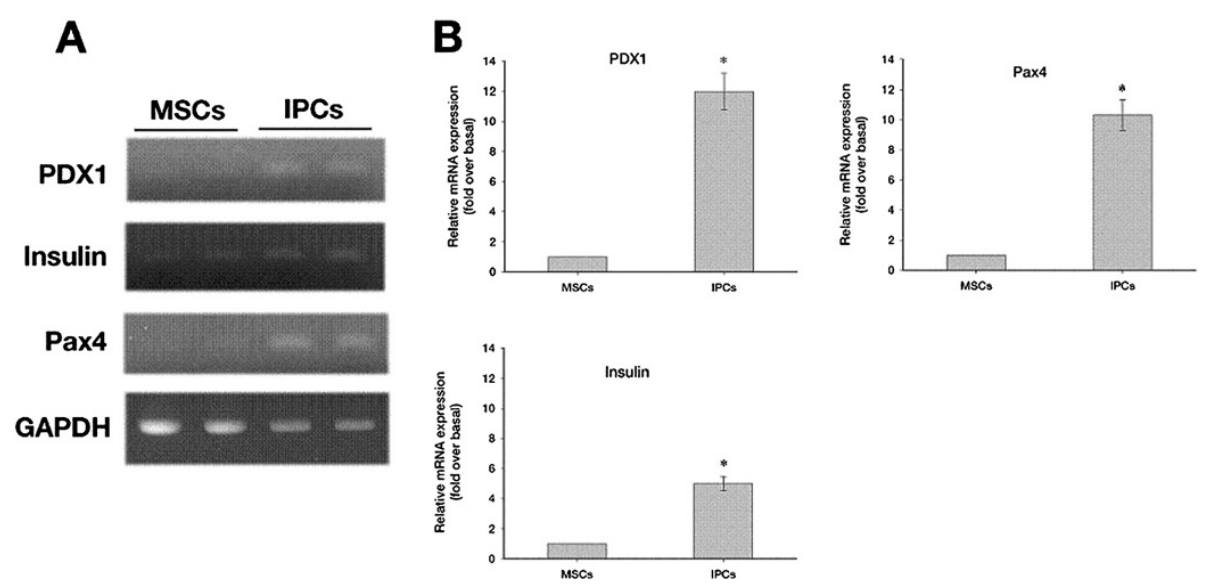

Figure 2 Reverse transcriptase and real-time PCR analysis of the expression of pancreatic $\beta$-cell development-related genes and insulin production-related genes. (A) Reverse transcriptase -PCR results for non-differentiated cells (MSCs, lane 1 and 2), differentiated cells (IPCs, lane 3 and 4). (B) Real-time PCR analysis of the expression of Pax4, Pax 1 and Insulin. Results are expressed as the mean \pm SEM for 4 experiments. ${ }^{*}, P<0.05$ compared to the non-differentiated cells.

\section{Secretion of C-peptide by insulin-producing cells upon glucose stimulation}

$\mathrm{C}$-peptide is a byproduct of new insulin formation. The concentration of C-peptide in the undifferentiated and differentiated cells, measured by ELISA, showed that these cells secreted higher levels of C-peptide than the pretreatment cells (Figure 2A). To determine whether these insulin-producing cells were responsive to glucose challenge, $\mathrm{C}$-peptide secretion was measured. As shown in Figure 5, the differentiated cells secreted around 50 $\mathrm{pmol} / \mathrm{L}$ of C-peptide at a low glucose concentration $(5.5 \mathrm{mM})$ and approximately five as much at a high glucose concentration $(25 \mathrm{mM})$.

\section{Effect on STZ rats blood sugar changes after cell transplantation}

The rats began to show hyperglycemia on the final day of STZ treatment. In the study group, blood sugar levels were reduced significantly 4 weeks after transplantation ( $\mathrm{P}$ $<0.05$ ) (Figure 6A). The STZ group showed hyperglycemia.

\section{Immunofluorescent staining for human C-peptide and human cell nuclei of the rat livers after transplantation}

By six weeks post-transplantation, insulin-producing cell function was evidenced by the appearance of both human $\mathrm{C}$-peptide and human cell nuclei in the same location within the lobules of the rat liver (Figure 6B and 6C). Conversely, neither the human $\mathrm{C}$-peptide or human cell nuclei were detected in the Sham group (data not shown). These findings suggest that the insulin-secreting cells differentiated from human Wharton's jelly stem cells were able to function as islet-like structures following transplantation.

\section{Discussion}

Adult bone marrow-derived cells can be induced to differentiate into insulin-producing cells under defined conditions [17]. Stem cell regeneration is an attractive insulin replacement therapy for those with insulin dependent DM. Stem cells from the pancreas [34,35], bone marrow [29], umbilical cord blood [25], and embryo [36] have previously been used in research on regeneration therapies for DM. Recently, we found that Wharton's jelly from the human umbilical cord contains fibroblast-like cells, which are similar to MSCs [26]. In this study, we investigated the ability of these cells to differentiate into insulin-producing cells, as well as the potential curative effects of transplanting the insulin-producing cells into the livers of diabetic rats. Simultaneously, we tested the usefulness of the modified Port-A catheter in transplantation.

Our results illustrate that human umbilical cord MSCs could be differentiated into insulin-producing cells following incubation under specific conditions [17]. Based on current references of pancreas endocrine cell development, a combination of various factors, including activin A, sodium butyrate, growth factors in serum free media supplements were used in this study (Figure 1).

Due to the controversy surrounding insulin uptake by cells from media supplements [37,38], we used human Cpeptide to characterize insulin production by our cells. Proinsulin, the precursor of insulin, is composed of 3 segments, the A-chain, B-chain, and C-peptide. Although C-peptide is released from proinsulin, unlike the A- and B-chains, it is not taken up by the cells. Thus, levels of C-peptide can be used as a marker of insulin secretion. After exposure of MSCs to differentiation conditions, immunocytochemical 


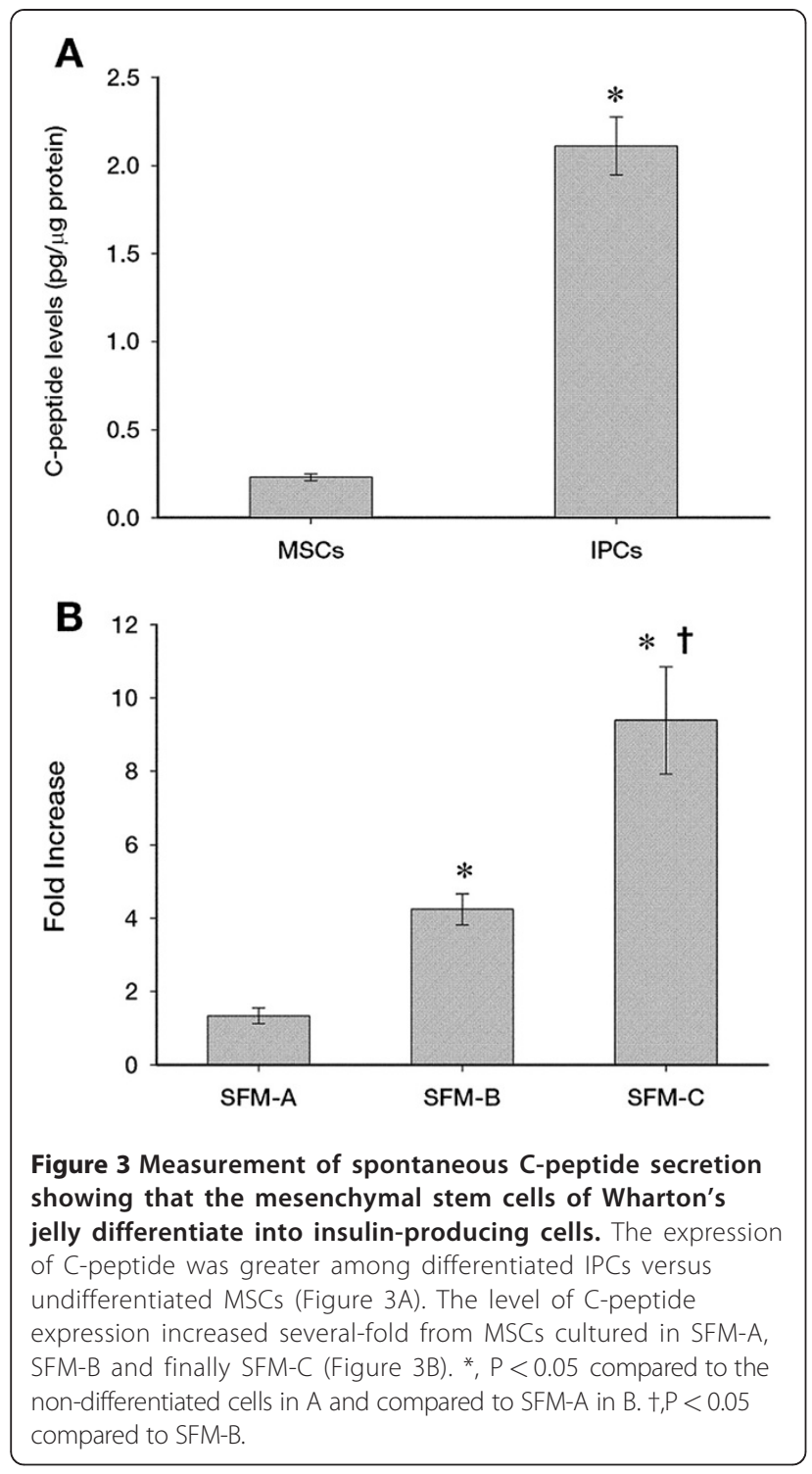

staining revealed that the cells expressed both insulin and C-peptide.

In a prior study we demonstrated that pancreatic endocrine precursor (PEP) cells could be generated from human umbilical cord MSCs [27]. In our in vitro studies, expression of $\beta$-cell development-related genes was examined by reverse transcriptase and real time PCR before and after induction of differentiation. After differentiation for 17 days, the insulin-producing cells expressed the following pancreatic $\beta$-cell development-related genes: Pax4, Nkx2.2, MafA, NeuroD, Isl-1, Glut2 and insulin. Additionally, our Cpeptide secretion assays revealed that the differentiated cells generated in vitro displayed functional characteristics of insulin-producing cells. After the cells were transplanted into the NOD mice via a retro-orbital vein, blood sugar levels tended to decrease [27].
In this study, Wharton's jelly was induced to differentiate into islet-like cell aggregates. After differentiation for 10 days, the insulin-producing cells expressed the following pancreatic $\beta$-cell development-related genes: Pax4, Pax1 and insulin. Additionally, we found greater expression of C-peptide in differentiated versus undifferentiated MSCs (Figure 1A). After the cells were transplanted into the STZ induced rats via a portal, we found that blood sugar levels tended to decrease in comparison to STZ rats receiving sham transplantation. This method of developing insulin-producing cells was more effective, inexpensive and less time consuming.

In the current study, Wharton's jelly tissue was used as opposed to pancreatic stem cells, as the former contains much greater quantities of stem cells than the pancreatic duct. Specifically, each cubic centimeter of Wharton's jelly sample contains $1-1.5 \times 10^{4}$ MSCs and the number of cells increases 300 -fold after seven passages, providing a plentiful supply of cells for transplantation. In addition, the use of Wharton's jelly stem cells is preferable to embryonic stem (ES) cells, as doing so avoids the risk of teratoma formation as well as the ethical issues inherent in using ES cells.

The portal vein [39], renal subcapsular space [28], and tail vein [29] have been previously used as stem cell transplant locations for insulin regeneration therapies in the rat. In this study, cells were transplanted into the rat liver via the portal vein. Interestingly, we have observed that blood sugar levels tend to decrease sooner when using hepatic portal vein transplantation instead of renal subcapsular transplantation [28]. These results are likely related to the finding that transplantation into the liver is more advantageous than renal subcapsular transplantation for diabetes therapy, as the former technique provides a larger surface area for implantation and recapitulates an orthotopic site physiologically. Specifically, secreted insulin enters the portal system (via the superior mesenteric vein) rather than the systemic venous system (via the renal vein) [40]. In our previous study [27], transplantation of insulinproducing cells via the retro-orbital vein was used to treat NOD mice. Though techniquely it is easier to perform and less invasive than via portal vein, higher mortality rate in mice and less number $\left(1 \times 10^{5}\right)$ of MSCs could be used were the major obstacles. Transplantation of MSCs via retro-orbital vein may only be used for the smaller animals. It has been reported that insulin-producing cells were injected directly into liver parenchymal of STZ induced diabetic rats to lower blood glucose level [41]. However, this transplantation method applied to clinical setting is limited. In clinical application, the Edmonton Protocol involves isolating islets from a cadaveric donor pancreas. Each recipient needs to transplant islets isolated from one to as many as three donors. The islets are infused into the patient's portal vein, then these islets are stored at the liver 

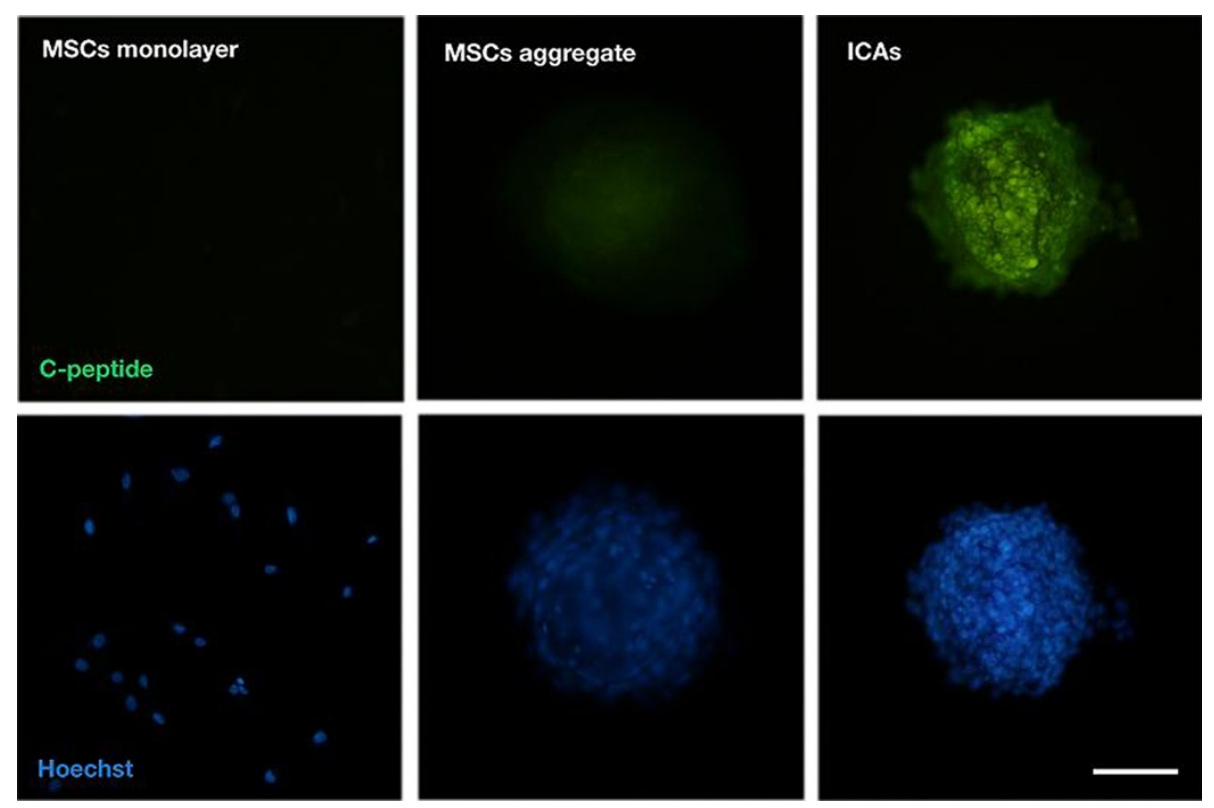

Figure 4 Immunocytochemical staining for C-peptide. The MSCs were induced into islet-like cell clusters (ICAs) which contain C-peptide labeling cells, indicating that the induced MSCs could aggregate and form functional pancreatic endocrine cells. Bar $=50 \mu \mathrm{m}$.

to produces insulin. For clinical application to use hMSCs as a cell transplantation source for diabetic regeneration therapy, proof of usefulness of hMSCs transplantation via the portal vein in a large animal diabetic model is needed.

In order to test the function of the MSC-derived insulinproducing cells in vivo, we transplanted the differentiated cells into STZ-induced DM rats via a Port-A catheter into the portal vein. The modified Port-A catheter used in this study has two main advantages over techniques described

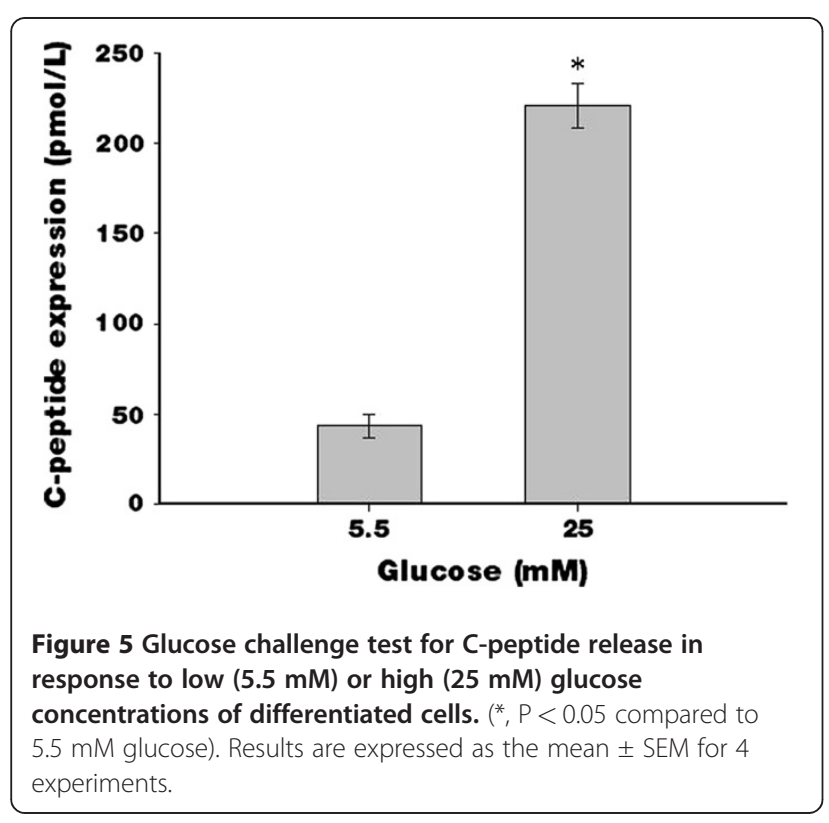

in previous studies. First, since only a very small part of the catheter is inserted into the widest part of the portal vein, no veins are clamped permanently, in contrast to previous methods $[42,43]$, and the disturbance to intestinal blood flow is minimized. Additionally, the use of a port enhances catheter longevity, thereby permitting longer periods of infusion. Indeed, the reported duration of use of a Port-A catheter is 9-34 months [44].

Following transplantation of insulin-producing cells into diabetic rats in the current study, C-peptide was found in the transplanted cells of the liver and blood glucose levels decreased. Both of these findings suggest that the transplanted cells secreted functional insulin. Indeed, on the fourth week after transplantation, blood glucose levels decreased to approximately $250 \mathrm{mg} / \mathrm{dl}$ in the compared to $530 \mathrm{mg} / \mathrm{dl}$ in the STZ controls. Nevertheless, we believe that transplantation may slow down the appearance of symptoms of DM rather than cure the disease.

\section{Conclusion}

Our results show that human MSCs derived from umbilical cord can differentiate into pancreatic lineage cells in vitro and function as insulin-producing cells both in vitro and in vivo. Thus, these cells are a promising stem cell source for $\beta$-cell regeneration. Additionally, the modified Port-A catheter used in this study is an important method for the transplantation of insulin-producing cells. Further work is required to examine the curative effects on larger animal models and humans. 

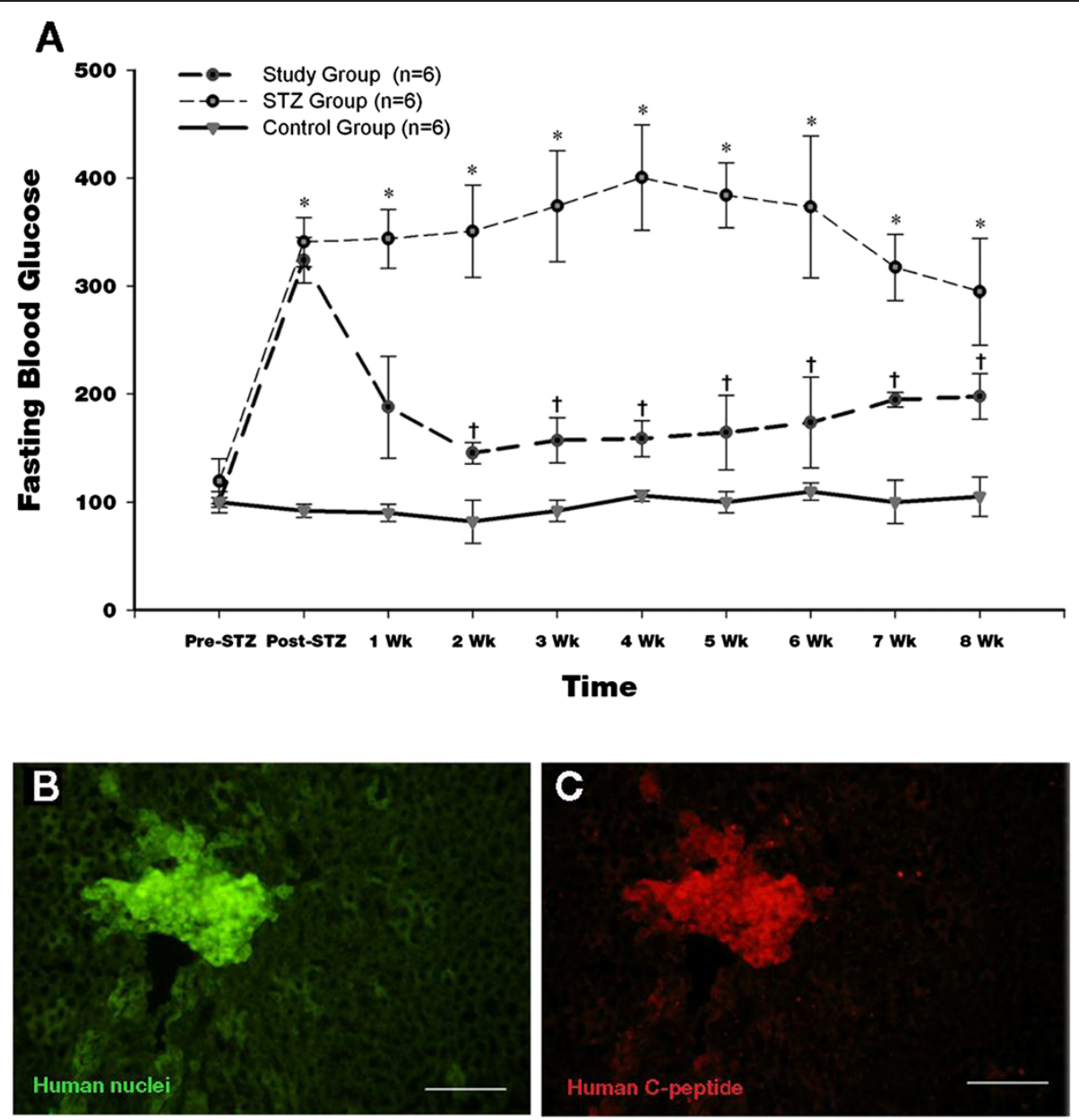

Figure 6 (A) Changes in blood glucose levels in STZ-induced diabetic rats after transplantation of insulin-producing cells into the portal vein via the Port-A catheter (study group), non-transplanted STZ-induced diabetic rats (STZ group), and normal non-diabetic rats. ${ }^{*}, \mathrm{P}<0.05$ compared to control group;,$+ \mathrm{P}<0.05$ compared to STZ group). Results are presented as the mean \pm SEM for 6 rats. Doubleimmunostaining for human C-peptide and human nuclei in the liver of the STZ-induced diabetic rats at 8 weeks after transplantation of insulinproducing cells. (B) Stained with anti-human nuclei antibody (green). (C) Stained with anti-human C-peptide antibody (red). Bars $=100 \mu \mathrm{m}$.

\section{Competing interests}

The authors declare that they have no competing interests.

\section{Acknowledgments}

This work was funded by Grants from Taipei Veterans General Hospital (V99E1-004 and V99C1-201) and Program for Progress Towards Top-Level University in National Yang Ming University to T-H Chen; National Science Council Grant, NSC 98-2314-B-075-015-MY3, to Y-M Shyr and NSC 97-2320-B010-019-MY3, to H-S Wang; Medical Research Grant, TSGH-C101-121 and NDMC-D101-3-3, to J-F Shyu.

\section{Author details}

${ }^{1}$ Institute of Clinical Medicine, National Yang-Ming University, Taipei, Republic of China. ${ }^{2}$ Department of Emergency, Division of Surgery, Veteran General Hospital, Taipei, Republic of China. ${ }^{3}$ Institute of Anatomy and Cell Biology, School of Medicine, National Yang Ming University, 201 Shih-Pai Road Section 2, Taipei 112, Republic of China. ${ }^{4}$ Department of Surgery, Veteran General Hospital, Taipei, Republic of China. ${ }^{5}$ Division of Cardiovascular Surgery, Cardiovascular Center, Taipei Medical University Hospital, Taipei, Republic of China. ${ }^{6}$ Department of Biology and Anatomy, National Defense Medical Center, 161 Ming Chuan E. Road Section 6, Taipei 114, Republic of China.

\section{Authors' contributions}

All authors participated in various aspects of the study analysis and interpretation of the data, and to the development of the report. The final version was seen and approved by all authors.

Received: 11 February 2012 Accepted: 30 April 2012

Published: 30 April 2012

\section{References}

1. Bottazzo GF, Florin-Christensen A, Doniach D: Islet-cell antibodies in diabetes mellitus with autoimmune polyendocrine deficiencies. Lancet 1974, 2:1279-1283.

2. Gepts W: Pathologic anatomy of the pancreas in juvenile diabetes mellitus. Diabetes 1965, 14:619-633.

3. Larsen JL: Pancreas transplantation: indications and consequences. Endocr Rev 2004, 25:919-946.

4. Ryan EA, Lakey JR, Rajotte RV, Korbutt GS, Kin T, Imes S, Rabinovitch A, Elliott JF, Bigam D, Kneteman NM, Warnock GL, Larsen I, Shapiro AM: Clinical outcomes and insulin secretion after islet transplantation with the Edmonton protocol. Diabetes 2001, 50:710-719.

5. Shapiro AM, Lakey JR, Ryan EA, Korbutt GS, Toth E, Warnock GL, Kneteman NM, Rajotte RV: Islet transplantation in seven patients with type 1 
diabetes mellitus using a glucocorticoid-free immunosuppressive regimen. N Eng J Med 2000, 343:230-238.

6. Yamaoka T: Regeneration therapy of pancreatic beta cells: towards a cure for diabetes? Biochem Biophys Res Commun 2002, 296:1039-1043.

7. Matsumoto S, Noguchi H, Hatanaka N, Shimoda M, Kobayashi N, Jackson A, Onaca N, Naziruddin B, Levy MF: Estimation of donor usability for islet transplantation in the United States with the kyoto islet isolation method. Cell Transplant 2009, 18:549-556.

8. Kobayashi N, Yuasa T, Okitsu T: Regenerative medicine for diabetes mellitus. Cell Transplant 2009, 18:491-496.

9. Friedenstein AJ, Piatetzky S II, Petrakova KV: Osteogenesis in transplants of bone marrow cells. J Embryol Exp Morphol 1966, 16:381-390.

10. Lennon DP, Edmison JM, Caplan Al: Cultivation of rat marrow-derived mesenchymal stem cells in reduced oxygen tension: effects on in vitro and in vivo osteochondrogenesis. J Cell Physiol 2001, 187:345-355.

11. Pittenger MF, Mackay AM, Beck SC, Jaiswal RK, Douglas R, Mosca JD, Moorman MA, Simonetti DW, Craig S, Marshak DR: Multilineage potential of adult human mesenchymal stem cells. Science 1999, 284:143-147.

12. Sekiya I, Vuoristo JT, Larson BL, Prockop DJ: In vitro cartilage formation by human adult stem cells from bone marrow stroma defines the sequence of cellular and molecular events during chondrogenesis. Proc Natl Acad Sci U S A 2002, 99:4397-4402.

13. Alvarez-Dolado M, Pardal R, Garcia-Verdugo JM, Fike JR, Lee HO, Pfeffer $K$, Lois C, Morrison SJ, Alvarez-Buylla A: Fusion of bone-marrow-derived cells with Purkinje neurons, cardiomyocytes and hepatocytes. Nature 2003, 425:968-973.

14. Fukuda K: Development of regenerative cardiomyocytes from mesenchymal stem cells for cardiovascular tissue engineering. Artif Organs 2001, 25:187-193.

15. Hakuno D, Fukuda K, Makino S, Konishi F, Tomita Y, Manabe T, Suzuki Y, Umezawa A, Ogawa S: Bone marrow-derived regenerated cardiomyocytes (CMG Cells) express functional adrenergic and muscarinic receptors. Circulation 2002, 105:380-386.

16. Orlic D: Adult bone marrow stem cells regenerate myocardium in ischemic heart disease. Ann N Y Acad Sci 2003, 996:152-157.

17. Jiang J, Au M, Lu K, Eshpeter A, Korbutt G, Fisk G, Majumdar AS: Generation of insulin-producing islet-like clusters from human embryonic stem cells. Stem Cells 2007, 25:1940-1953.

18. Pereira RF, Hume EL, Halford KW, Prockop DJ: Bone fragility in transgenic mice expressing a mutated gene for type I procollagen (COL1A1) parallels the age-dependent phenotype of human osteogenesis imperfecta. J Bone Miner Res 1995, 10:1837-1843.

19. Pereira RF, O'Hara MD, Laptev AV, Halford KW, Pollard MD, Class R, Simon D, Livezey K, Prockop DJ: Marrow stromal cells as a source of progenitor cells for nonhematopoietic tissues in transgenic mice with a phenotype of osteogenesis imperfecta. Proc Natl Acad Sci U S A 1998, 95:1142-1147.

20. Ferrari G, Cusella-De Angelis G, Coletta M, Paolucci E, Stornaiuolo A, Cossu $\mathrm{G}$, Mavilio F: Muscle regeneration by bone marrow-derived myogenic progenitors. Science 1998, 279:1528-1530.

21. Pereira RF, Halford KW, O'Hara MD, Leeper DB, Sokolov BP, Pollard MD, Bagasra O, Prockop DJ: Cultured adherent cells from marrow can serve as long-lasting precursor cells for bone, cartilage, and lung in irradiated mice. Proc Natl Acad Sci U S A 1995, 92:4857-4861.

22. Spees JL, Olson SD, Ylostalo J, Lynch PJ, Smith J, Perry A, Peister A, Wang MY, Prockop DJ: Differentiation, cell fusion, and nuclear fusion during ex vivo repair of epithelium by human adult stem cells from bone marrow stroma. Proc Natl Acad Sci U S A 2003, 100:2397-2402.

23. Karnieli O, Izhar-Prato Y, Bulvik S, Efrat S: Generation of insulin-producing cells from human bone marrow mesenchymal stem cells by genetic manipulation. Stem Cells 2007, 25:2837-2844.

24. Chandra V, Phadnis S, Nair PD, Bhonde RR: Generation of pancreatic hormone-expressing islet-like cell aggregates from murine adipose tissue-derived stem cells. Stem Cells 2009, 27:1941-1953.

25. Parekh VS, Joglekar MV, Hardikar AA: Differentiation of human umbilical cord blood-derived mononuclear cells to endocrine pancreatic lineage. Differentiation 2009, 78:232-240.

26. Wang HS, Hung SC, Peng ST, Huang CC, Wei HM, Guo YJ, Fu YS, Lai MC, Chen CC: Mesenchymal stem cells in the Wharton's jelly of the human umbilical cord. Stem Cells 2004, 22:1330-1337.

27. Wang HS, Shyu JF, Shen WS, Hsu HC, Chi TC, Chen CP, Huang SW, Shyr YM, Tang KT, Chen TH: Transplantation of insulin producing cells derived from umbilical cord stromal mesenchymal stem cells to treat NOD mice. Cell Transplant 2011, 20(3):455-466

28. Suen PM, Li K, Chan JC, Leung PS: In vivo treatment with glucagon-like peptide 1 promotes the graft function of fetal islet-like cell clusters in transplanted mice. Int J Biochem Cell Biol 2006, 38:951-960

29. Banerjee M, Kumar A, Bhonde RR: Reversal of experimental diabetes by multiple bone marrow transplantation. Biochem Biophys Res Commun 2005, 328:318-325.

30. Hussain MA, Theise ND: Stem-cell therapy for diabetes mellitus. Lancet 2004, 364:203-205.

31. Serup P, Madsen OD, Mandrup-Poulsen T: Islet and stem cell transplantation for treating diabetes. BMJ 2001, 322:29-32.

32. Siminovitch L, McCulloch EA, Till JE: The distribution of colony-forming cells among Spleen colonies. J Cell Physiol 1963, 62:327-336.

33. Yoshida S, Ishikawa F, Kawano N, Shimoda K, Nagafuchi S, Shimoda S, Yasukawa M, Kanemaru T, Ishibashi H, Shultz LD, Harada M: Human cord blood-derived cells generate insulin-producing cells in vivo. Stem Cells 2005, 23:1409-1416.

34. Hansson M, Tonning A, Frandsen U, Petri A, Rajagopal J, Englund MC, Heller RS, Hakansson J, Fleckner J, Skold HN, Melton D, Semb H, Serup P: Artifactual insulin release from differentiated embryonic stem cells. Diabetes 2004, 53:2603-2609.

35. Ryu S, Kodama S, Ryu K, Schoenfeld DA, Faustman DL: Reversal of established autoimmune diabetes by restoration of endogenous beta cell function. J Clin Invest 2001, 108:63-72.

36. Shah R, Jindal RM: Reversal of diabetes in the rat by injection of hematopoietic stem cells infected with recombinant adeno-associated virus containing the preproinsulin II gene. Pancreatology 2003, 3:422-428.

37. Golosow N, Grobstein C: Epitheliomesenchymal interaction in pancreatic morphogenesis. Dev Biol 1962, 4:242-255.

38. Rajagopal J, Anderson WJ, Kume S, Martinez Ol, Melton DA: Insulin staining of ES cell progeny from insulin uptake. Science 2003, 299:363.

39. Lopez-Talavera JC, Garcia-Ocana A, Sipula I, Takane KK, Cozar-Castellano I, Stewart AF: Hepatocyte growth factor gene therapy for pancreatic islets in diabetes: reducing the minimal islet transplant mass required in a glucocorticoid-free rat model of allogeneic portal vein islet transplantation. Endocrinology 2004, 145:467-474.

40. McEvoy RC, Hegre OD: Syngeneic transplantation of fetal rat pancreas. III. Effect of insulin treatment on the growth and differentiation of the pancreatic implants after reversal of diabetes. Diabetes 1979, 28:141-146.

41. Chao KC, Chao KF, Fu YS, Liu SH: Islet-like clusters derived from mesenchymal stem cells in Wharton's Jelly of the human umbilical cord for transplantation to control type 1 diabetes. PLoS One 2008, 1:e1451.

42. Beattie GM, Lopez AD, Otonkoski T, Hayek A: Transplantation of human fetal pancreas: fresh vs. cultured fetal islets or ICCS. J Mol Med 1999, 77:70-73.

43. Soria B, Roche E, Berna G, Leon-Quinto T, Reig JA, Martin F: Insulinsecreting cells derived from embryonic stem cells normalize glycemia in streptozotocin-induced diabetic mice. Diabetes 2000, 49:157-162.

44. Liu JC, Tseng HS, Chen CY, Chern MS, Chang CY: Percutaneous retrieval of 20 centrally dislodged Port-A catheter fragments. Clin Imaging 2004, 28:223-229.

doi:10.1186/1423-0127-19-47

Cite this article as: Tsai et al:: Transplantation of insulin-producing cells from umbilical cord mesenchymal stem cells for the treatment of streptozotocin-induced diabetic rats. Journal of Biomedical Science 2012 19:47. 